\title{
International variation in socioeconomic inequalities in self reported health
}

\author{
Anton E Kunst, José J M Geurts, Jaap van den Berg
}

\begin{abstract}
Study objective - To assess the extent to which the size of socioeconomic inequalities in self reported health varies among industrialised countries.

Design - Cross sectional data on the association between educational level and several health indicators were obtained from national health interview surveys. This association was quantified by means of an inequality index based on logistic regression analysis.
\end{abstract}

Setting - The national, non-institutionalised populations of the United Kingdom, Sweden, Denmark, Germany, The Netherlands, Italy, the United States, and Canada were studied. The age group was 15-64 years, and the study period was 1983-90.

Participants - Representative population samples with the number of respondents ranging from approximately 6000 (Denmark) to 90000 (the United States) were studied.

Main results - For men, the smallest health inequalities were observed for the United Kingdom and Sweden, and the largest inequalities for Italy and the United States. Other countries held an intermediate position. The same international pattern was observed for women, except that relatively small inequalities were also observed for Dutch women.

Conclusions - The results agree to a large extent with those of previous comparative studies. The international pattern observed here may be partly related to "subjective" aspects of self reported health, such as the propensity to complain and illness behaviour. The results challenge the view that disease and disability are distributed less equally in the UK than in countries like Sweden.

Department of Pub

Medicine and

Health Sciences,

Erasmus University, PO Box 1738,

3000 DR Rotterdam,

The Netherlands

A E Kunst

Department for

Health Statistics,

Netherlands Central

Bureau of Statistics,

Heerlen,

The Netherlands

J J M Geurts

J van den Berg

Correspondence to:

Dr A E Kunst.

Accepted for publication June 1994 lands are larger than in Sweden, this would suggest that there is potential for reducing health inequalities in The Netherlands, and that a more detailed comparison with the Swedish situation might show in which way a reduction might be achieved.

Most studies on international variation in health inequalities have focussed on mortality instead of morbidity. ${ }^{6-9}$ There is, however, a rich and up to date source of data in respect of morbidity: national health interview and level of living surveys, which include several questions on the health and socioeconomic status (SES) of respondents. ${ }^{10}$ These surveys usually cover various aspects of health such as perceived general health, the presence of chronic conditions and physical complaints, short and long term disability, and positive health indicators such as height.

We consider here whether data from health interview surveys in various industrialised countries show about equally large socioeconomic inequalities in reported health, or whether important differences exist. A comparison will be made between several countries and in respect of a number of health indicators.

\section{Methods}

DATA

Requests for data on the prevalence of health problems in relation to age, sex, and socioeconomic group were sent to national bureaux of statistics or similar institutions in a large number of countries. Data were requested for nine health indicators on factors including perceived general health, physical complaints, chronic conditions, short term and long term disability, and height. Data were obtained for 13 countries: The Netherlands, Denmark, Norway, Sweden, Finland, the United Kingdom (UK), France, Germany, Italy, Spain, the United States (USA), Canada, and Japan. On the average five health indicators were obtained per country. An analysis of this extensive data set is reported elsewhere. ${ }^{11}$

It has frequently been pointed out that cross country comparisons of indicators of SES and indicators of self reported health may be prone to substantial biases. ${ }^{12-13}$ In order to reduce comparability problems as far as possible, the analysis presented here is restricted in four ways as detailed below:

(1) Comparisons are made by using achieved educational level as the only socioeconomic indicator. The cross country comparability of another common socioeconomic indicator, occupational class, was found to be much more problematic than that of edu- 
cation. ${ }^{14} \mathrm{~A}$ third socioeconomic indicator, income, was excluded because data on this indicator were available for only three countries.

Table 1 Surveys included in the study

\begin{tabular}{lllr}
\hline Country & Period & Survey & Sample size \\
\hline The Netherlands & $1983-85$ & Health interview survey & 22228 \\
& $1986-88$ & Idem & 20725 \\
& $1989-90$ & Idem & 13060 \\
Denmark & $1989-90$ & Continuous quality of life survey & 7756 \\
Sweden & $1986-87$ & Health and morbidity survey & 6285 \\
United Kingdom & $1980-81$ & Survey of living conditions & 14457 \\
Germany & $1988-89$ & Idem & 12431 \\
& 1988 & General household survey & 19716 \\
Italy & $1984-86$ & National health (examination and) & 15714 \\
Canada & $1986-87$ & Survey on health conditions of & 43507 \\
United States & 1985 & population and the use of health services & 19409 \\
\hline & 1990 & Health promotion survey & $\mathbf{2}$ \\
\hline
\end{tabular}

Table 2 Health indicators included in the study

\begin{tabular}{ll}
\hline Health indicator & Proposed measure: \% of respondents that . . . \\
\hline $\begin{array}{l}\text { Perceived general health } \\
\text { Short term disability: reduction in } \\
\text { daily activities }\end{array}$ & $\begin{array}{l}\text { Consider their present state of health less than good } \\
\text { Had to cut down on usual activities at least one day } \\
\text { in the past } 2 \text { weeks, because of injury or temporary } \\
\text { Long term disability: OECD list }\end{array}$ \\
$\begin{array}{l}\text { Mention one or more disabilities when asked for by } \\
\text { means of the OECD list ('eg carrying weight, climbing } \\
\text { stairs, reading newspaper) } \\
\text { Reply positively to an open question similar to "Do } \\
\text { you suffer from any long standing illness, disease or } \\
\text { disability?" } \\
\text { Average body height }\end{array}$ \\
\hline
\end{tabular}

Table 3 Educational classifications available for this study

\begin{tabular}{|c|c|c|}
\hline \multirow[t]{2}{*}{ Country } & \multicolumn{2}{|l|}{ Educational categories } \\
\hline & National terminology & $O E C D$ level $^{*}$ \\
\hline \multirow[t]{5}{*}{ The Netherlands } & Basisschool & 1 \\
\hline & LBO/MAVO & 2 \\
\hline & MBO/HAVO/VWO & 3 \\
\hline & $\mathrm{HBO} /$ universiteit $\leq 3 \mathrm{y}$ & $4 a$ \\
\hline & Universiteit $>3 \mathrm{y}$ & $4 \mathrm{~b}$ \\
\hline \multirow[t]{4}{*}{ Denmark } & Grundskole, $\leq 6 \mathrm{y}$ & 1 \\
\hline & Grundskole, 8-9y & $2 \mathrm{a}$ \\
\hline & Grundskole, $10 \mathrm{y}$ & $2 b$ \\
\hline & Gymnasieskole/etc & 3,4 \\
\hline \multirow[t]{7}{*}{ Sweden } & Grundskolan, $\leq 8 \mathrm{y}$ & 1 \\
\hline & Grundskolan, $9 \mathrm{y}$ & 2 \\
\hline & Gymnasieskolan, 1 y & $3 a$ \\
\hline & Gymnasieskolan, 2 y & $3 b$ \\
\hline & Gymnasieskolan, $>2$ y & $3 c$ \\
\hline & Högskolan, $\leq 3 \mathrm{y}$ & $4 \mathrm{a}$ \\
\hline & Högskolan, $>3 \mathrm{y}$ & $4 \mathrm{~b}$ \\
\hline \multirow[t]{7}{*}{ United Kingdom } & Left school before $15 \mathrm{y}$ & $\dagger$ \\
\hline & Left school at $15 \mathrm{y}$ & \\
\hline & $\begin{array}{l}\text { Left school at } 10 \mathrm{y} \\
\text { Left school at } 17 \mathrm{y}\end{array}$ & \\
\hline & Left school at $18 \mathrm{y}$ & \\
\hline & Left school at $19-21 \mathrm{y}$ & \\
\hline & Left school at $22-24$ y & \\
\hline & Left school after $24 \mathrm{y}$ & \\
\hline \multirow[t]{3}{*}{ Germany } & Volksschule/Hauptschule & $1,2 \mathrm{a}$ \\
\hline & Mittlere reife/Realschule & $2 b, 3$ \\
\hline & Fachhochschulreife/Abitur & 4 \\
\hline \multirow[t]{4}{*}{ Italy } & Scuole elementari & 1 \\
\hline & Scuole medie & 2 \\
\hline & Licei/instituti tecnici/etc & 3 \\
\hline & Università/accademie/etc & 4 \\
\hline \multirow[t]{4}{*}{ United States } & Elementary/middle school & $1,2 \mathrm{a}$ \\
\hline & Junior high school & $2 b$ \\
\hline & (Senior) high school & 3 \\
\hline & College/university/etc & 4 \\
\hline \multirow[t]{3}{*}{ Canada } & Elementary school & 1 \\
\hline & Secondary school & 2,3 \\
\hline & Degree or diploma & 4 \\
\hline
\end{tabular}

* Educational level according to a standardised scheme developed by the OECD. ${ }^{15}$

$1=$ first level

$2=$ second level, first stage

$3=$ second level, second stag

$4=$ third level

We made further distinctions with the letters "a" (low), "b" and "c" (high).

† No correspondence to the OECD scheme of educational levels.
(2) Countries for which the classification of people by achieved educational level produced a very skewed distribution - that is, where more than half of the population was assigned to a single educational category - are excluded. The UK could be included in the present study only by using an approximate educational measure with an even population distribution: the age at leaving school (less than $14,15,16 \ldots$ more than 25 years).

(3) A third restriction refers to health indicators, which are included only if the corresponding survey questions had approximately the same structure and content in each country. The indicators on short term disability (bed days), long term disability (the activities of daily living (ADL) list), health complaints, and chronic conditions are excluded. The questions corresponding to these indicators differed between countries with regard to, among others, the length of reference periods and the content of check lists on ADL items, health complaints, and chronic conditions.

(4) Age groups under 16 years and over 65 years are excluded from analysis because these were not represented in all surveys. An additional reason for excluding people over 65 years is that this reduces any bias in health inequality estimates that might result from the fact that the institutionalised population was excluded from the data for all countries.

As a consequence of these restrictions, five of the 13 countries had to be excluded from analysis, and for the eight remaining countries data were used for an average of 2.5 health indicators. The remaining countries and their respective surveys are presented in table 1 , health indicators are presented in table 2 , and educational classifications are presented in table 3.

One remaining data problem should be mentioned. For the indicator on perceived general health, the number and wording of the response categories varied by country. This resulted in artificial cross country variation in the overall prevalence of respondents reporting less than good health. In addition, we found for various countries that lower overall prevalence rates that is, restriction to people with relatively serious health problems - are associated with larger inequality estimates. Therefore, overall prevalence rates will have to be taken into account when comparing countries in terms of the size of inequalities in perceived general health.

\section{Methods}

Countries were compared by means of an inequality index, which, for each country, measures the size of health inequalities between educational groups. This index is a modified version of the relative index of inequality of $\mathrm{Pa}$ muk, ${ }^{16}$ which is equivalent to the concentration index that has been advocated by Wagstaff et al. ${ }^{9}$ The main advantage of these indices is that all educational groups are included in the assessment of inequalities in health. In addition, these indices do not measure all health differences between educational groups, 
but only the differences that are systematically related to an ordering of groups from high to low SES.

The inequality index is calculated in two steps. In the first step, the SES of each educational group is quantified. In order to do this, the status of an educational group is conceptualised as the relative position of this group on the social hierarchy. More specifically, SES is equated to the proportion of the population with a higher position on the social hierarchy. For example, if the highest educational group comprises $10 \%$ of the population, the relative position of its members is between 0 and $0 \cdot 1$, the average being 0.05 .

In the second step, this SES measure is related to the prevalence of a health problem by means of regression analysis. Because of the dichotomous nature of the dependent variable, logistic regression was applied. The regression equation is:

$$
\begin{gathered}
\hat{\mathrm{H}}_{\mathrm{ij}}=\mathrm{N}_{\mathrm{ij}}{ }^{*} \mathrm{P}_{\mathrm{ij}} \\
\mathrm{P}_{\mathrm{ij}}=\frac{\mathrm{e}^{\alpha_{\mathrm{i}} \beta S E S_{j}}}{1+\mathrm{e}^{\alpha_{\mathrm{i}} \beta S E S_{j}}}
\end{gathered}
$$

where $\hat{H}$ is the predicted number persons with the health problem; $\mathrm{N}$ is the total number of respondents; $p$ is the proportion of the respondents with the health problem; SES is socioeconomic status; $i$ and $j$ represent 10 year age group and socioeconomic group respectively; and $\alpha$ and $\beta$ are regression coefficients.

Exponentiation of the regression coefficient $\beta$ results in an odds ratio with the following interpretation: the ratio of the odds predicted for the bottom of the social hierarchy (SES = 1) to the odds predicted for the top of the social hierarchy $(S E S=0)$, with the odds corresponding to the proportion of subjects with the health problem. If the proportion of positive cases is small (say, less than $0 \cdot 10$ ), the odds ratio can be interpreted as the relative risk for having the health problem at the bottom compared with the risk at the top of the hierarchy.

An assumption underlying the regression model is that after logistic transformation, the relationship between SES and prevalence rates is linear. This assumption was checked for by means of visual inspection of residuals and a test on the statistical significance of a quadratic term for the SES measure. Substantial and statistically significant non-linearities were not detected.

An important corollary of linearity is that the inequality index does not depend strongly on the number of different educational groups. If the association between SES and health were perfectly linear, then virtually the same logistic regression coefficient would be found whether there were eight or, say, three educational groups. In that case, the only condition for carrying out international comparisons is that the educational categories distinguished are in a strictly hierarchical order. Indeed, the surveys included in the present study all classified educational groups strictly from high to low level. The only possible exception, the UK, will be considered in the Discussion section.

What is important to the interpretation of the inequality index is that it includes two distinct phenomena which both are relevant to socioeconomic inequalities in health. This can be illustrated as follows. If the odds ratio for a country is large compared with the odds ratios for other countries, this implies large health differences between high and low positions on the social hierarchy. These large health differences can be attributed to large differences between high and low social positions in respect of the level of education or a large health effect of a one unit increase in the level of education (for example, one year of additional education), or both. Thus, the inequality index combines inequalities in levels of education as well as the effect of education on health. This index therefore measures the total size of health differences in a population that are related to educational inequality.

\section{Results}

The total size of health differences related to educational inequality, as measured by odds ratios, is presented in tables 4 to 8 for each health indicator respectively. We will first discuss results for men, which are given in the left of each table.

MEN

Table 4 concerns perceived general health, as measured by the percentage of respondents that consider their own state of health as less than good. As explained at the end of the Methods section, overall prevalence rates will

\begin{tabular}{|c|c|c|c|c|}
\hline \multirow[t]{3}{*}{ Country } & \multicolumn{2}{|l|}{ Men } & \multicolumn{2}{|l|}{ Women } \\
\hline & $\begin{array}{l}\text { Prevalence in total } \\
\text { population (\%) }\end{array}$ & $\begin{array}{l}\text { Magnitude of differences } \\
\text { between } S E \text { groups }\end{array}$ & $\begin{array}{l}\text { Prevalence in total } \\
\text { population (\%) }\end{array}$ & $\begin{array}{l}\text { Magnitude of differences } \\
\text { between } S E \text { groups }\end{array}$ \\
\hline & & OR $(95 \% C I)$ & & OR $(95 \% C I)$ \\
\hline $\begin{array}{l}\text { The Netherlands } \\
\text { Denmark } \\
\text { Sweden } \\
\text { United Kingdom } \\
\text { United States } \\
\text { Canada }\end{array}$ & $\begin{array}{r}15 \cdot 3 \\
16 \cdot 9 \\
17 \cdot 4 \\
8 \cdot 6 \\
31 \cdot 4 \\
8 \cdot 0 \\
27 \cdot 3 \\
10 \cdot 1 \\
38 \cdot 6\end{array}$ & $\begin{array}{c}4 \cdot 55(4 \cdot 00,5 \cdot 18) \\
4 \cdot 24(2 \cdot 78,6 \cdot 45) \\
3 \cdot 05(2 \cdot 50,3 \cdot 72) \\
4 \cdot 25(2 \cdot 95,6 \cdot 12) \\
2 \cdot 43(1 \cdot 99,2 \cdot 98) \\
13 \cdot 90(11 \cdot 80,16 \cdot 30) \\
10 \cdot 10(9 \cdot 20,11 \cdot 10) \\
6 \cdot 16(4 \cdot 58,8 \cdot 30) \\
3 \cdot 79(3 \cdot 19,4 \cdot 50)\end{array}$ & \begin{tabular}{r|}
$18 \cdot 3$ \\
$18 \cdot 8$ \\
$20 \cdot 3$ \\
$10 \cdot 2$ \\
$37 \cdot 3$ \\
$9 \cdot 6$ \\
$34 \cdot 6$ \\
$10 \cdot 4$ \\
$35 \cdot 5$
\end{tabular} & $\begin{array}{c}3 \cdot 31(2 \cdot 93,3 \cdot 73) \\
5 \cdot 52(3 \cdot 68,8 \cdot 28) \\
2 \cdot 89(2 \cdot 39,3 \cdot 48) \\
3 \cdot 73(2 \cdot 75,5 \cdot 07) \\
3 \cdot 20(2 \cdot 66,3 \cdot 84) \\
13 \cdot 40(11 \cdot 60,15 \cdot 50) \\
6 \cdot 37(5 \cdot 86,6 \cdot 93) \\
3 \cdot 57(2 \cdot 69,4 \cdot 73) \\
2 \cdot 65(2 \cdot 22,3 \cdot 15)\end{array}$ \\
\hline
\end{tabular}

Table 4 Educational differences in perceived general health in six countries: age group 16-64 years

$\mathrm{SE}=$ socioeconomic; $\mathrm{OR}=$ odds ratio; $(95 \% \mathrm{CI})=95 \%$ confidence interval. 
Table 5 Educational differences in activity restriction in five countries: age group 16-64 years

\begin{tabular}{|c|c|c|c|c|}
\hline \multirow[t]{3}{*}{ Country } & \multicolumn{2}{|l|}{ Men } & \multicolumn{2}{|l|}{ Women } \\
\hline & \multirow[t]{2}{*}{$\begin{array}{l}\text { Prevalence in total } \\
\text { population (\%) }\end{array}$} & $\begin{array}{l}\text { Magnitude of differences } \\
\text { between SE groups }\end{array}$ & \multirow[t]{2}{*}{$\begin{array}{l}\text { Prevalence in total } \\
\text { population (\%) }\end{array}$} & $\begin{array}{l}\text { Magnitude of differences } \\
\text { between SE groups }\end{array}$ \\
\hline & & OR $(95 \% C I)$ & & OR $(95 \% C I)$ \\
\hline $\begin{array}{l}\text { The Netherlands } \\
\text { Denmark } \\
\text { Sweden } \\
\text { United Kingdom } \\
\text { Italy }\end{array}$ & $\begin{array}{r}11 \cdot 3 \\
9 \cdot 3 \\
8 \cdot 5 \\
9 \cdot 6 \\
12 \cdot 5\end{array}$ & $\begin{array}{l}1.73(1.50,2.00) \\
1.70(1.03,2 \cdot 80) \\
1.06(0.82,1 \cdot 36) \\
0.86(0.64,1 \cdot 15) \\
2.35(1.98,2 \cdot 79)\end{array}$ & $\begin{array}{l}12 \cdot 8 \\
11 \cdot 0 \\
11 \cdot 0 \\
12 \cdot 9 \\
14 \cdot 7\end{array}$ & $\begin{array}{l}1 \cdot 17(1 \cdot 02,1 \cdot 35) \\
1 \cdot 11(0 \cdot 71,1 \cdot 75) \\
0 \cdot 87(0 \cdot 69,1 \cdot 09) \\
1 \cdot 10(0 \cdot 86,1 \cdot 41) \\
1 \cdot 74(1 \cdot 49,2 \cdot 03)\end{array}$ \\
\hline
\end{tabular}

Table 6 Educational differences in any long standing health problem in four countries: age group 16-64 years

\begin{tabular}{|c|c|c|c|c|}
\hline \multirow[t]{3}{*}{ Country } & \multicolumn{2}{|l|}{ Men } & \multicolumn{2}{|l|}{ Women } \\
\hline & \multirow[t]{2}{*}{$\begin{array}{l}\text { Prevalence in total } \\
\text { population (\%) }\end{array}$} & $\begin{array}{l}\text { Magnitude of differences } \\
\text { between SE groups }\end{array}$ & \multirow[t]{2}{*}{$\begin{array}{l}\text { Prevalence in total } \\
\text { population (\%) }\end{array}$} & $\begin{array}{l}\text { Magnitude of differences } \\
\text { between } S E \text { groups }\end{array}$ \\
\hline & & OR $(95 \% C I)$ & & OR $(95 \% C I)$ \\
\hline $\begin{array}{l}\text { The Netherlands } \\
\text { Denmark } \\
\text { Sweden } \\
\text { United Kingdom }\end{array}$ & $\begin{array}{l}24 \cdot 9 \\
28 \cdot 4 \\
34 \cdot 0 \\
32 \cdot 0\end{array}$ & $\begin{array}{l}2.45(2 \cdot 05,2 \cdot 94) \\
2.52(1 \cdot 81,3 \cdot 50) \\
1.91(1.64,2 \cdot 23) \\
1.72(1.42,2 \cdot 09)\end{array}$ & $\begin{array}{l}25 \cdot 9 \\
28 \cdot 4 \\
36 \cdot 5 \\
31 \cdot 3\end{array}$ & $\begin{array}{l}1 \cdot 76(1 \cdot 47,2 \cdot 10) \\
2.63(1 \cdot 89,3 \cdot 67) \\
1 \cdot 78(1 \cdot 53,2 \cdot 08) \\
1 \cdot 85(1 \cdot 53,2 \cdot 24)\end{array}$ \\
\hline
\end{tabular}

Table 7 Educational differences in long term disability (OECD list) in three countries: age group 16-64 years

\begin{tabular}{|c|c|c|c|c|}
\hline \multirow[t]{3}{*}{ Country } & \multicolumn{2}{|l|}{ Men } & \multicolumn{2}{|l|}{ Women } \\
\hline & $\begin{array}{l}\text { Prevalence in total } \\
\text { population (\%) }\end{array}$ & $\begin{array}{l}\text { Magnitude of differences } \\
\text { between } S E \text { groups }\end{array}$ & $\begin{array}{l}\text { Prevalence in total } \\
\text { population (\%) }\end{array}$ & $\begin{array}{l}\text { Magnitude of differences } \\
\text { between } S E \text { groups }\end{array}$ \\
\hline & & OR $(95 \% C I)$ & & OR $(95 \% C I)$ \\
\hline $\begin{array}{l}\text { The Netherlands } \\
\text { Denmark } \\
\text { Germany }\end{array}$ & $\begin{array}{l}5 \cdot 4 \\
5 \cdot 8 \\
4 \cdot 1\end{array}$ & $\begin{aligned} 6 \cdot 72 & (5 \cdot 05,8 \cdot 95) \\
7 \cdot 34 & (3 \cdot 49,15 \cdot 40) \\
14 \cdot 80 & (6 \cdot 71,32 \cdot 51)\end{aligned}$ & $\begin{array}{l}8 \cdot 1 \\
7 \cdot 7 \\
6 \cdot 7\end{array}$ & $\begin{array}{l}4 \cdot 73(3 \cdot 72,6 \cdot 01) \\
6 \cdot 41(3 \cdot 42,12 \cdot 00) \\
5 \cdot 38(3 \cdot 10,9 \cdot 34)\end{array}$ \\
\hline
\end{tabular}

Table 8 Educational differences in height in four countries: age group 25-64 years

\begin{tabular}{|c|c|c|c|c|}
\hline \multirow[t]{3}{*}{ Country } & \multicolumn{2}{|l|}{ Men } & \multicolumn{2}{|l|}{ Women } \\
\hline & \multirow{2}{*}{$\begin{array}{l}\text { Average height } \\
\text { total population } \\
(\mathrm{cm})\end{array}$} & $\begin{array}{l}\text { Magnitude of differences } \\
\text { between } S E \text { groups }\end{array}$ & \multirow{2}{*}{$\begin{array}{l}\text { Average height } \\
\text { total population } \\
(\mathrm{cm})\end{array}$} & \multirow{2}{*}{$\begin{array}{l}\text { Magnitude of differences } \\
\text { between SE groups } \\
\text { Regression coefficient }(95 \% \mathrm{CI})\end{array}$} \\
\hline & & Regression coefficient (95\% CI) & & \\
\hline $\begin{array}{l}\text { The Netherlands } \\
\text { Denmark } \\
\text { Sweden } \\
\text { Germany }\end{array}$ & $\begin{array}{l}178 \cdot 3 \\
177 \cdot 6 \\
177 \cdot 6 \\
176 \cdot 1\end{array}$ & $\begin{array}{l}-4 \cdot 72(-4 \cdot 12,-5 \cdot 33) \\
-6 \cdot 28(-5 \cdot 18,-7 \cdot 39) \\
-3 \cdot 50(-2 \cdot 65,-4 \cdot 35) \\
-4 \cdot 80(-3 \cdot 91,-5 \cdot 69)\end{array}$ & $\begin{array}{l}166 \cdot 6 \\
165 \cdot 5 \\
164 \cdot 5 \\
164 \cdot 3\end{array}$ & $\begin{array}{l}-2 \cdot 87(-2 \cdot 35,-3 \cdot 39) \\
-3.57(-2 \cdot 68,-4 \cdot 46) \\
-2 \cdot 36(-1 \cdot 77,-2 \cdot 94) \\
-3.02(-2 \cdot 37,-3.67)\end{array}$ \\
\hline
\end{tabular}

have to be taken into account. The overall prevalence of men with less than good health is about 15 to $20 \%$ in The Netherlands, Denmark, and Sweden. Odds ratios for Denmark and The Netherlands are equally large, while odds ratios for Sweden are smaller.

Overall prevalence rates of about $10 \%$ are observed for the UK (less than fair), the USA (less than good), and Canada (less than good). The next higher cut off point (less than good/ less than very good) yields overall rates of about $35 \%$. For the UK, odds ratios at both cut off points are smaller than those for The Netherlands and Denmark, and on average as large as those for Sweden. For the USA, odds ratios for both cut off points are sizeably larger than those for The Netherlands and Denmark. Canada is in between the UK and the USA, and has odds ratios of the same order of magnitude as those for The Netherlands and Denmark.

Table 5 concerns activity restriction, as measured by the percentage of respondents who, because of temporary illness or injury, had to cut down on their usual activities at least one day in the last two weeks. Odds ratios for The Netherlands and Denmark are equally large, while those for Sweden and the UK are smaller.
Much larger odds ratios are observed for Italy. Not included in table 5 are data from the USA on activity restriction. These data were not supplied as the proportion of respondents with activity restriction, but as the average number of days of activity restriction. A comparison with Dutch data was made by extracting Dutch survey data of the same type as that for the USA. For both countries, the association between the numbers of days of activity restriction and educational level was determined by means of Poisson regression. Significantly larger regression estimates were observed for the USA. It was estimated that the number of days of activity restriction at rank $=1$ was 3.06 times larger than that at rank $=0$. The corresponding estimate for The Netherlands is $2 \cdot 39$.

Table 6 concerns any long standing health problem, as measured by the percentage of respondents that reply in the affirmative to an open question on the presence of long standing health problems. Again, odds ratios for The Netherlands and Denmark are equally large, while odds ratios for Sweden and the UK are smaller.

Table 7 concerns long term disability, as 
Table 9 Health differences between groups with high education and groups with intermediate or low education: the United Kingdom and The Netherlands; males 15-64 years*

\begin{tabular}{|c|c|c|c|c|c|}
\hline \multirow[t]{2}{*}{ Country } & \multirow{2}{*}{$\begin{array}{l}\text { Achieved } \\
\text { educational } \\
\text { level }\end{array}$} & \multirow{2}{*}{$\begin{array}{l}\text { No of } \\
\text { respondents } \\
(\%)\end{array}$} & \multicolumn{3}{|c|}{ Age adjusted prevalence ratef } \\
\hline & & & $\begin{array}{l}\text { Perceived general } \\
\text { health }\end{array}$ & $\begin{array}{l}\text { Reduction in daily } \\
\text { activities }\end{array}$ & $\begin{array}{l}\text { Any long standing } \\
\text { health problem }\end{array}$ \\
\hline NL & $\begin{array}{l}\text { Post-secondary } \\
\text { Lower }\end{array}$ & $\begin{array}{l}22 \\
78\end{array}$ & $\begin{array}{r}8 \cdot 27 \\
17 \cdot 16 \\
(2 \cdot 07)\end{array}$ & $\begin{array}{r}9 \cdot 79 \\
12 \cdot 83 \\
(1 \cdot 31)\end{array}$ & $\begin{array}{l}20 \cdot 20 \\
27 \cdot 25 \\
(1 \cdot 35)\end{array}$ \\
\hline UK & $\begin{array}{l}\text { College } \\
\text { Lower }\end{array}$ & $\begin{array}{l}22 \\
78\end{array}$ & $\begin{array}{l}26.83 \\
32.56 \\
(1.21)\end{array}$ & $\begin{array}{r}11 \cdot 12 \\
9 \cdot 31 \\
(0.84)\end{array}$ & $\begin{array}{l}28.99 \\
32.67 \\
(1 \cdot 13)\end{array}$ \\
\hline \multirow[t]{2}{*}{ UK } & $\begin{array}{l}\text { Left school at } \\
19+y\end{array}$ & 16 & 24.04 & $11 \cdot 23$ & $28 \cdot 37$ \\
\hline & Lower & 84 & $\begin{array}{l}32 \cdot 16 \\
(1 \cdot 34)\end{array}$ & $\begin{array}{c}9 \cdot 29 \\
(0 \cdot 83)\end{array}$ & $\begin{array}{l}32 \cdot 18 \\
(1 \cdot 13)\end{array}$ \\
\hline
\end{tabular}

* Sources: general household survey (1988), health interview survey (1989-90).

† In \%. Indirect standardisation. Between brackets: ratio low/high educational level.

measured by the percentage of respondents that mention one or more disabilities when asked to by means of the OECD list. Odds ratios for The Netherlands and Denmark are equally large. Odds ratios for Germany are larger, although not with statistical significance.

Table 8 concerns height. Since height is a continuous variable instead of a dichotomous variable, the association with educational level was determined by means of weighted leastsquares regression instead of logistic regression. The resulting regression coefficient can be interpreted as the absolute difference between rank $=0$ and rank $=1$ in predicted height (in $\mathrm{cm}$, controlling for age). In all countries, people with low educational level are shorter. Height differences in The Netherlands and Germany are equally large. Smaller differences are observed for Sweden and larger differences for Denmark.

\section{WOMEN}

The total size of health differences related to educational inequality in women is given in the right hand columns of tables 4 to 8 . The pattern of international variation in health inequalities among women corresponds closely to that observed for men. For example, health inequality estimates for Sweden and the UK are smaller than, or as small as, those for any other country. Furthermore, in the comparison between The Netherlands and the USA with regard to activity restriction, significantly larger inequality estimates were obtained for the USA $(2 \cdot 13)$ than for The Netherlands $(1 \cdot 38)$. The major exception is that health inequalities among women in The Netherlands are as small as, instead of being larger than, those in Sweden and the UK.

\section{SUMMARY}

The total size of health differences related to educational inequality varies between countries, at least according to data from health interview surveys. Relatively small health inequalities are observed in surveys from the UK and Sweden, while larger health inequalities are observed for The Netherlands and Denmark. The few health indicators for Germany and Canada showed about equally large health inequalities as for The Netherlands and Denmark. The few health indicators for Italy and the USA show substantially larger inequalities.

\section{Discussion}

The results reinforce the impression from published reports that socioeconomic inequalities in health are a generalised phenomenon in the industrialised world. At the same time, substantial cross country variation was found in the total size of health differences related to educational inequality. This study therefore suggests that inequality in health is not an invariable phenomenon, and that in some countries at least there is a large potential for reducing health inequalities.

A likely problem with using data from different health interview surveys is that these surveys have been designed for different purposes and with different methodologies. ${ }^{10}$ Three aspects of intersurvey differences are of relevance to the present study.

\section{Intersurvey differences}

DIFFERENCES IN THE GENERAL CHARACTERISTICS OF THE SURVEY POPULATION The surveys we have included are all representative of the national, non-institutionalised population aged 15 to 64 years. Nonresponse rates in most surveys are low and in the same order of magnitude (1-20\%). In The Netherlands and Germany, however, non-response rates are over $30 \%$. Non-response biases health inequality estimates if it is related to SES and, given a SES, to health status. Indeed, non-response has been found to be higher in lower social strata. ${ }^{17}$ The relation with health status is uncertain. Thus, inequality estimates for The Netherlands and Germany have larger margins of uncertainty than those for the other countries.

\section{DIFFERENCES IN THE MEASUREMENT AND} CLASSIFICATION OF EDUCATION

The classification of respondents according to the achieved level of education differs between surveys, partly as a reflection of international differences in educational systems. ${ }^{15}$ More important to the present study, however, is that 
in each survey the educational classification was hierarchical and detailed. This permitted the calculation, for each country separately, of the inequality index on the basis of which countries could be compared.

The UK is a special case. Here we had to rely on a proxy measure for the achieved level of education: the age at leaving school. This measure fails to take into account, among other factors, part time education and the type of education followed. A large part of the population left school soon after the legal minimum leaving age of 14 years, which raises questions on the validity of subdividing school leavers of about 16 years and below. In view of these problems, we made additional comparisons between the UK and one reference country, The Netherlands. In table 9, prevalence rates are presented for men with a high educational level and men with intermediate and low levels. In both countries, the group with a clearly high level of education make up $22 \%$ of all men. Again, the smallest inequalities in health are consistently found for the UK. The last line of the table also shows that a comparable measure on the basis of age at leaving school (left school before 19 years, or later) yields nearly identical inequality estimates for the UK, which suggests that no serious bias occurred in the application of the latter measure.

This study used education as the socioeconomic indicator because education has been judged to be internationally more comparable than occupation..$^{14}$ Although in individual populations education and occupation are strongly correlated, with correlations typically being about 0.50 , the question remains whether the same international pattern of health inequalities would be observed when using occupation as the socioeconomic indicator. The answer is, probably, yes. According to data from health interview surveys, the total size of health differences related to occupational status is about equally large in Sweden and the UK, and relatively large in The Netherlands and Denmark. ${ }^{911} 18-20$

\section{DIFFERENCES IN THE MEASUREMENT OF HEALTH} INDICATORS

The health indicators considered here are based on questions with a similar structure and content in each survey. Another way of assessing the comparability of survey questions on health indicators are the overall proportions of positive responses: these proportions are approximately the same in each country (tables 5 to 7 ). Certainly, the fact that survey questions and overall prevalence rates are not identical for all countries may have introduced bias into the measurement of international variation in health inequalities. The fact that the same international pattern of health inequalities is consistently found for each health indicator, however, suggests that such incidental biases have had only a modest effect.

A more fundamental problem with regard to health indicators is that they depend on reporting by subjects. Self reports of health status do not only depend on the presence of "objective" health problems, but also on the perception of these health problems, the behavioural response to perceived health problems, and the propensity to report health problems and related behaviour. ${ }^{21}$ Perhaps the subjective nature of these indices should not be exaggerated: even the most subjective health indicator, the perception of one's own state of health, is strongly associated with the prevalence of objective health problems and survival. ${ }^{22}$ However, the possibility that differential reporting has obscured a part of the "objective" inequalities in some countries while inflating observed health inequalities in other countries cannot be excluded.

Uncertainty about the size of potential bias related to "subjective" factors raises the question of how the results compare with international comparisons in respect of an evidently "objective" health indicator mortality..$^{6-92324}$ The agreement is fairly strong. A common finding is that inequalities are relatively large in Italy and the USA, but small in Sweden. A notable discrepancy occurs with the $\mathrm{UK}$, where inequalities in mortality, but not in self reported health, are larger than in Sweden, Denmark, and The Netherlands. This discrepancy, however, is smaller than it may seem. First, mortality inequalities in the UK are relatively large only for the ages of 55 years and over, whereas inequalities among younger age groups are of the same size as in Sweden and similar countries. ${ }^{723}$ It may be no surprise then that health interview surveys, which give less weight to older age groups than mortality data, give a more favourable impression of the relative position of the UK. Secondly, even though inequalities in mortality in the UK are relatively large for ages above 55 years, they still are fairly small from a wider international perspective. ${ }^{24}$ Thus, the international pattern of inequalities in self reported health correspond largely to the pattern found for mortality.

In conclusion, studies which rely on a comparison of health interview surveys are bound to produce results with large margins of uncertainty. Probably most important is the fact that "subjective" aspects of self reported health will have determined the results to some, but an unknown, extent. Nevertheless, the results may be viewed with some confidence. Among other things they challenge the common view that in the UK disease and disability are distributed less equally than in countries like Sweden.

\section{Some tentative explanations}

Cross country comparisons provide a new opportunity of identifying circumstances that are associated with large or small inequalities in health. A relevant question therefore is why the extent of health inequalities varies between countries.

The first explanation relates to the selection hypothesis, which states that health and education are in part related because educational achievement depends partly on health or health related factors. ${ }^{25}$ The contribution of health selection to the generation of health inequalities 
in adult life has been hotly debated, especially in the UK, but is bound to be the subject of conjecture as long as life long longitudinal studies are not carried out. Important for the present study is the fact that, as West pointed out, the magnitude of health selection is likely to vary between countries as a function of educational and training structures. ${ }^{25}$ Future assessments of international variation in educational systems may therefore contribute to understanding the size of health inequalities in different countries.

The alternative explanation relates to the causation hypothesis, which stresses the effect of educational level on health. The higher morbidity rates of low educational groups are at least partly explained by a higher prevalence of risk factors for disease and disability, such as factors related to life styles, material living conditions, working conditions, and (coping with) stress. A logical extension of this assertion is that international variation in the social distribution of risk factors explains at least partly the international variation in health inequalities. For example, the small differences in height in Sweden suggest that the small health differences in this country can be partly attributed to small inequalities in factors related to life circumstances in childhood, such as dietary factors or the experience of poverty.

The small inequalities in Sweden inevitably remind us of the fact that during various decades conscious policies were carried out to improve the living conditions of the most disadvantaged sections of the Swedish population. The suggestion of a positive effect of egalitarian policies on health inequalities is nothing new. ${ }^{62627}$ What we add, however, are new pieces of evidence: Italy and the USA, the two included countries with the largest income inequalities, ${ }^{2829}$ are precisely those with the largest inequalities in self reported health. Thus, the international pattern of inequalities in health supports the view that health inequalities are sensitive to egalitarian social and economic policies.

This study would have been impossible without the supply of unpublished data by $\mathbf{N}$ Rasmussen (data on Denmark), I Petersson and K Ödeen-Björling (Sweden), L Sanders and $R$ Butcher (the United Kingdom), C Bormann and U Helmer (West Germany), L Roveri (Italy), G Hendershot (USA), and D Fowler Graham (Canada). We are indebted to Johan Mackenbach for his comments on previous versions of this paper.
1 Fox AJ ed. Health inequalities in European countries. Aldershot: Gower, 1989.

2 Illsley R, Svensson P-G eds. Social inequalities in health Soc Sci Med 1990;31 (special issue)

3 Mielck A, Rosário G, Rosario M, eds. Inequalities in health and health care. Review of selected publications from 18 wester European countries. Munich: MEDIS, 1993.

4 Mackenbach JP. Socio-economic health differences in the Netherlands: a review of recent empirical findings. Soc Sci Med 1992;34:213-26.

5 Marmot MG, Kogevians M, Elston MA. Social/economic status and disease. Annu Rev Public Health 1987;8:111-35.

6 Vagero D, Lundberg O. Health inequalities in Britain and Sweden. Lancet 1989;ii:35-6.

7 Valkonen T. Adult mortality and level of education: a comparison of six countries. In: Fox J ed. Health inequalities in European countries. Aldershot: Gower, 1989:142-72.

8 Leclerc A, Lert F, Fabien C. Differential mortality: som comparisons between England and Wales, Finland and France, based on inequalities measures. Int $\mathcal{f}$ Epidemio 1990;4:1-10.

9 Wagstaff A, Paci P, Doorslaer E van. On the measurement of inequalities in health. Soc Sci Med 1991;33:545-57.

10 Evers S. Health-for-all indicators in health interview surveys. Voorburg: Netherlands Central Bureau of Statistics, 1991.

11 Netherlands Central Bureau for Statistics, Erasmus University, Rotterdam. International variation in socio-economic inequalities in self-reported health. The Hague: SDU-publishers/CBS-publications, 1992

12 Aiach P, Curtis S. Social inequalities in self-reported morbidity: interpretation and comparison of data from Britain and France. Soc Sci Med 1990;31:267-74.

13 Baxter M. A comparison of measures of inequality in morbidity. In: Fox J ed. Health inequalities in European countries. Aldershot: Gower, 1989:199-230.

14 Valkonen T. Problems in the measurement and international comparisons of socio-economic differences in mortality. Soc Sci Med 1993;36:409-18.

15 OECD. Education in OECD countries 1987-99. A compendium of statistical information. 1990 special edition. Paris: OECD, 1990.

16 Pamuk ER. Social class and inequality in mortality from 1921 to 1972 in England and Wales. Population Studies 1985;39:17-31.

17 Heer WF de, Israëls AZ. Response trends in Europe. Voorburg, the Netherlands: Netherlands Central Bureau of Statistics, 1992 (report no 13136-92-M1).

18 Lahelma E, Valkonen T. Health and social inequities in Finland and elsewhere. In: Illsley R, Svensson P-G eds. Health inequities in Europe. Soc Sci Med 1990 27(special issue):257-65.

19 Karisto A. Health from the point of well-being: experiences in the Scandinavian welfare survey. Proceedings of the international symposium on health conduct and health care in the modern symposium on health conduct and health
welfare state. Bad Homburg, 1987.

20 Lundberg O. Class and health: comparing Britain and Sweden. Soc Sci Med 1986;23:511-17.

21 Blaxter M. Health and lifestyles. London: Tavistock/Routledge, 1990.

22 Idler EL, Angel RJ. Self-rated health and mortality in the NHANES-1 epidemiological follow-up study. Am $\mathcal{F}$ Public Health 1990;80:446-52.

23 Kunst AE, Mackenbach JP. The size of mortality differences associated with educational level. A comparison of 9 industrialized countries. Am $\mathcal{F}$ Public Health 1994;84:932-7.

24 Kunst AE, Mackenbach JP. International variation in the size of mortality differences associated with occupational status. Int $\mathcal{f}$ Epidemiol 1994;23:742-50.

25 West P. Rethinking the health selection explanation for health inequalities. Soc Sci Med 1991;32:373-84.

26 Davey Smith G, Bartley M, Blane D. The Black report on socioeconomic inequalities in health 10 years on. $B M \mathcal{F}$ socioeconomic ined

27 Dahlgren G, Whitehead M. Policies and strategies to promote equity in health. Copenhagen: WHO, 1992.

28 United Nations, Department of International Economic and Social Affairs. National accounts statistics: compendium of income distribution statistics. New York: UN, 1985. Statistical papers, series $M$; no 79 .

29 Smeeding TM, Coder J. Income inequality in rich countries during the 1980s. Luxembourg: CEPS/INSTEAD. 1993. The Luxembourg Income Study, working paper no 88. 